http://dx.doi.org/10.4314/jae.v18i2.19

\title{
Information and Training Sources Used by Rice Farmers in North Central Nigeria
}

Tsado, J. H., R.S. Olaleye, O. J. Ajayi, I. S. Umar and Ndatsu A. J.

Dept. of Agricultural Economics and Extension Technology,

Federal University of Technology, Minna, Niger State.

Corresponding author: jacobtsado2007@yahoo.com 08065268098

\section{Abstract}

The study investigated the information and training sources used by rice farmers in North central, Nigeria. A total of 320 respondents were selected and interviewed using structured interview schedule. The respondents were of two categories, the participants and non-participants of the intervention programme. The data were analyzed using frequency, percentages, mean, ranking and chi square. Majority (80.6\%) of the non-participants had been cultivating rice for more than 20 years and it was only few (10\%) of the participants that had been cultivating rice for more than 20 years, majority (91.3\%) of the participants had above 2.5 ha and only about 33.1\% of the non-participants had rice farm size above 2.5 ha. Many of the non-participants (57.5\%) had up to 3 different plots of rice farm, while the majority of the participants (51.3\%) had up to 2 different plots for rice farming. Non-participants and participants claimed that other farmers (93.1\%) and USAID/Market field officers (100\%) respectively were their main sources of information. Training perception indicates that selection of high yielding varieties with the mean score of 3.95 ranked $1^{\text {st }}$, selection of healthy seeds with a mean score of 3.92 ranked $2^{\text {nd }}$ and fertilizer use ranked $3^{\text {rd }}$ as the most relevant improved technologies on which training was received. The study also reveals that training was positively associated with adoption, the result of the paired mean difference between the output (35.863) and income (149113.8 ) of participants and non-participants showed clearly significant mean deference. Implying that training and adoption of improved rice package had a positive and significant effect on output and income. It was recommended that frequent training of the rice farmers in the study area should be given top-most priority so that the farmers can obtain adequate information and, consequently, obtain optimum yield from the adoption of improved rice packages.

Key words: Information, Training, Rice Farmers.

\section{Introduction}

Just as the communication environment (the totality and attributes of available information sources) of a farmer influences his information acquisition and utilization of technologies and packages, so, also, the farmers' communication behaviour may directly or indirectly influence his knowledge acquisition (Asiabaka, 2002). Agricultural extension is essentially an activity involving the dissemination of information about improved technologies to the end users (Asiabaka 2002). For any technology to be accepted and adopted the farmers must not only, first of all, know about it but also must have positive perception about it. Information available to farmers may come from different sources (CMMIT, 1993). Ganpat and Sespersad, (1996) emphasized that consistent interaction with an information source 
influence the adoption behaviour of farmers. Some farmers use limited communication sources, while others lend themselves to being more influenced by peculiar communication channel during different stages of innovation adoption. Agbamu (2006) stressed that adequate information is one of the major pre-requisite for widespread acceptance of agricultural innovation, such information usually abound through a variety of sources.

Training is an act of increasing the knowledge and skills of an employee in doing a particular job, (Filippo 1965 Ogunbameru, 2001).Training is mostly directed at improving the ability of individuals to do vocation more effectively and efficiently. Generally, it involves acquiring information, knowledge and developing abilities or attitudes, which will result in greater competence in the performance of a work. There are two main agents in training viz; the trainee and trainer. The active participation of both agents at every stage of the training programme is very important. A good understanding of the need is therefore fundamental to successful training. FARTA (2001) emphasized that training needs exists anytime an actual condition differs from a desirable conditions in the human or people aspect of organizational performances or more specifically when a change in present knowledge, skill and attitude can bring out the desired performance. Akinsehinde (2007) maintained that training needs, are skills, knowledge and attitude an individual requires in overcoming problems as well as avoiding creating problem situations. Trainers (teachers) are challenged to understand what the trainee (learner) knows from previous training and experience.

Perception is the process by which we receive information or stimuli from our environment and transform it into psychological awareness. It is difficult to understand the complex psychology of farmer's perception, but it is good to appreciate why farmers interpret training on various technologies differently (Van den Ban and Hawkins, 2002). It is also important to note that farmer's perception of improved rice technologies are relative rather than absolute, selective, organized and directional. The specific objectives of this study were to: identify some socio-economic characteristic of the rice farmers, identify rice farmers' sources of information and training, determine rice farmers' perception of the training on various types of improved rice technologies and explain the relationship between training and adoption of improved rice technologies.

\section{Methodology}

This study was conducted in North Central Zone of Nigeria. The area is located between latitude $6^{0} 30^{\prime}$ to $11^{\circ} 20^{\prime}$ North and longitude $2^{0} 30^{\prime}$ to $10^{\circ} 30^{\prime}$ East (Shuaib et al., 1997). More than $77 \%$ of the people in the region are rural dwellers and are mostly engaged in one form of agricultural activities or the other (Shuaib et al., 1997). Multi-stage sampling technique was used to select a total of 320 rice farmers from two of the rice growing states in the North Central Zone of the Country. First, in Niger State (Lavun and Gbako Local Governments areas), there were 12 and 11 active rice farmers' cooperative societies respectively and in Kwara State (Patigi and Edu Local Government Areas), there were 11 and 10 active rice farmers cooperative societies respectively. From each Local Government Areas 10 rice farmer's cooperative societies were randomly selected from a list that was obtained from USAID/MARKETS Field Officers from the two states. 
Secondly, four participating rice farmers were randomly selected from each of the cooperative societies, given a total of 40 members from each Local Government Area. Eighty participating rice farmers were selected from each state making a total of 160 participating farmers from the two states. In addition, equal numbers of non-participating farmers were randomly selected from each Local Government Areas from the two states, giving a total number of 160 non-participating rice farmers. The overall sampled respondents (participating and non-participating farmers) from the two states were three hundred and twenty (320).

Data were analyzed through the use of simple descriptive statistics, such as, frequency distribution, percentages, mean, ranking, Likert-type of scale and Chi square to test the relationship between training and adoption of improved rice technologies.

\section{Findings and Discussions}

\section{Respondents' socio-economic characteristics}

Rice farming experience as shown on Table 1 reveals that majority (80.6\%) of the nonparticipants had been cultivating rice for more than 20 years while it was only few (10\%) of the participants that had been cultivating rice for more than 20 years. about $37.6 \%$ of the participants had been cultivating rice for less than 11 years, for non-participants however, none had rice farming experience less than 10 years. This finding implies that young rice farmers participated in the programme than the older rice farmers. The findings is in conformity with that of Simonyan (2009) who reported that young farmers with less farming experience tend to participate more in other farming activities and programmes that could fetch them more income. 
Table 1: Distribution of respondents according to rice farming experience, rice farm size and number of rice plots

\begin{tabular}{|c|c|c|c|c|c|c|}
\hline \multirow[t]{2}{*}{ Variable } & \multicolumn{2}{|c|}{ Non-Participants } & \multicolumn{2}{|c|}{$\begin{array}{l}\text { Participants } \\
\end{array}$} & \multicolumn{2}{|c|}{ Total } \\
\hline & Frequency & Percentage & Frequency & Percentage & Frequency & Percentage \\
\hline \multicolumn{7}{|c|}{$\begin{array}{l}\text { Rice Farming } \\
\text { Experience }\end{array}$} \\
\hline$<5$ Years & - & - & 6 & 3.8 & 6 & 1.9 \\
\hline $6-10$ Years & - & - & 54 & 33.8 & 54 & 16.8 \\
\hline $11-15$ Years & 8 & 5.0 & 76 & 47.5 & 84 & 26.3 \\
\hline $16-20$ Years & 23 & 14.4 & 8 & 5.0 & 31 & 9.7 \\
\hline Above 20 & 129 & 80.6 & 16 & 10.0 & 145 & 45.3 \\
\hline Years & & & & & & \\
\hline $\begin{array}{l}\text { Total } \\
\text { Rice Farm }\end{array}$ & 160 & 100 & 160 & 100 & 320 & 100 \\
\hline Size (Ha) & & & & & & \\
\hline$<1.00$ & 5 & 3.1 & 2 & 1.3 & 7 & 2.1 \\
\hline $1.01-1.50$ & 21 & 13.1 & - & - & 21 & 6.6 \\
\hline $1.51-2.00$ & 33 & 20.6 & 5 & 3.1 & 38 & 11.9 \\
\hline $2.01-2.50$ & 48 & 30.0 & 7 & 4.4 & 55 & 17.2 \\
\hline Above 2.50 & 53 & 33.1 & 146 & 91.3 & 199 & 62.2 \\
\hline Total & 160 & 100 & 160 & 100 & 320 & 100 \\
\hline \multicolumn{7}{|l|}{$\begin{array}{l}\text { Number of } \\
\text { Rice Plots }\end{array}$} \\
\hline 1 & - & - & - & - & 0 & 0 \\
\hline 2 & 68 & 42.5 & 82 & 51.3 & 150 & 46.9 \\
\hline 3 & 92 & 57.5 & 78 & 48.8 & 170 & 53.1 \\
\hline Above 3 & & - & & - & 0 & 0 \\
\hline Total & 160 & 100 & 160 & 100 & 320 & 100 \\
\hline
\end{tabular}

Source: Field Survey, 2011

The result on table 1, also, reveals that majority (91.3\%) of the participants had above 2.5 ha and only about $33.1 \%$ of the non-participants had rice farm size above 2.5 ha. About $30 \%$ of the non-participants had rice farm size of between 2.01-2.50 ha and very few $(4.4 \%)$ of the participants had rice farm size between 2.01-2.50 ha. All other respondents had rice farm sizes of less than 2.01 ha. The result of the study indicates that most of the rice farmers in the study area were small scale farmers. The result agrees with that of Alfred, (2000); Olayide et al., (1980) who opined that smallness of farm size is a characteristic of the peasant farmers. The result in table 1 also showed that none of the respondents both participants and non-participants had only one plot of rice farm. Majority of the non-participants $(57.5 \%)$ had up to 3 different plots of rice farm, while the majority of the participants $(51.3 \%)$ had up to 2 different plots for rice farms. The result showed that rice farmers within the study area had between 2-3 different plots of rice farm. This may be attributed to the fact that land tenure systems, which normally results into excessive fragmentation of land is still a problem in the study area. This directly or indirectly affects farmers' efficiency. This finding is in agreement with that of Alene and Hassan (2003), who stated that land tenure system which normally result into excessive land fragmentation affects farmers' efficiency 


\section{Sources of Information and Training}

Adequate information is one of the major pre-requisites for widespread acceptance of agricultural technology. Such information usually abounds through a variety of sources. Table 2 shows that non-participants and participants claimed that other farmers (93.1\%) and USAID/Market field officers (100\%) respectively were their main sources of information, closely followed by extension agents accounting for $69.4 \%$ and $79.4 \%$ respectively for non-participants and participants.

Table 2: Distribution of respondents according to sources of information and training

\begin{tabular}{lll}
\hline $\begin{array}{l}\text { Sources of Information/ } \\
\text { training }\end{array}$ & Non-Participants & Participants \\
\hline Extension Agent & $111(69.4)$ & $127(79.4)$ \\
USAID/ Market Field & $2(1.3)$ & $160(100.0)$ \\
Officers & $149(93.1)$ & $147(91.9)$ \\
Other Farmers & $67(41.9)$ & $48(30.0)$ \\
Parents/ Relative/ Friends & $123(76.9)$ & $39(24.5)$ \\
Farmers Groups & $78(48.8)$ & \\
Progressive/ Contact & & $17(10.6)$ \\
Farmers & $46(28.8)$ & $146(91.3)$ \\
Land Owners & $141(88.1)$ & $145(90.6)$ \\
Mass/ Print Media & $99(61.9)$ & $153(95.6)$ \\
Field Days/ Agric Showed & $133(83.1)$ & \\
Demonstration &
\end{tabular}

*Multiple responses.

Source: Field Survey, 2011.

In the Training the Trainers programmes, there are usually chains of information flow and it continues to trickled down until the target population are covered. The results agree with that of Agbamu et al. (1996) who found that it is the village extension workers that farmers in Ogun State of Nigeria use most as source information.

\section{Perception of Information and Training Sources}

The result in table 3 shows that the respondents perceived all information sources as important in exception of progressive/contact farmers and land owners. Demonstration and other farmers ranked $1^{\text {st }}$ and $2^{\text {nd }}$ information sources they perceived as most important. This is closely followed by extension agents and USAID/MARKET Field Officers as $3^{\text {rd }}$ and $4^{\text {th }}$ information sources they perceived as important, this directly affect their rate of adoption. 
Table 3: Distribution of respondents according to perception of information and training sources

\begin{tabular}{|c|c|c|c|}
\hline & $\begin{array}{l}\text { Weighted } \\
\text { Mean }\end{array}$ & $\begin{array}{c}\text { Overall } \\
\text { Perception }\end{array}$ & Rank \\
\hline Extension Agent & 3.23 & Important & $3^{\text {rd }}$ \\
\hline USAID/ Market Field Officer & 3.07 & Important & $4^{\text {th }}$ \\
\hline Other Farmers & 3.27 & Important & $2^{\text {nd }}$ \\
\hline Parents/ Relatives/ Friends & 2.61 & Important & $7^{\text {th }}$ \\
\hline Progress/ Contact Farmers & 2.35 & Not Important & $8^{\text {th }}$ \\
\hline Land Owners & 1.92 & Not Important & $9^{\text {th }}$ \\
\hline Mass/ Print Media & 2.78 & Important & $6^{\text {th }}$ \\
\hline Field Days/ Agric Showed & 2.82 & Important & $5^{\text {th }}$ \\
\hline Demonstration Plots (SPAT & 3.47 & Important & $1^{\text {st }}$ \\
\hline
\end{tabular}

Figures in parenthesis are percentages

The respondents indicate varying degrees of perception about the relevance of training on different practices. Table 4 reveals that selection of high yielding varieties with the mean of 3.95 ranked $1^{\text {st }}$, selection of healthy seeds with a mean of 3.92 ranked $2^{\text {nd }}$ and fertilizer use ranked $3^{\text {rd }}$. It is possible to use high yielding varieties and select healthy seeds but without the availability of the required nutrient in the soil, the crop cannot give its optimal yield. This findings is in agreement with that of Negeu and Parikh (1999) and Gould et al. (1989) who stated that any practice that is not perceived as relevant by the farmers will not be accepted or adopted because they felt it is not relevant and or compatible with the existing practices.

\section{Perception on Training Received on Various types of Improved Rice Technologies}

Table 4 revealed that selection of high yielding varieties with the mean of 3.95 ranked $1^{\text {st }}$, selection of healthy seeds with a mean of 3.92 ranked $2^{\text {nd }}$ and fertilizer use ranked $3^{\text {rd }}$. It is possible to use high yielding varieties and select healthy seeds but without the availability of the required nutrient in the soil, the crop cannot give its optimal yield. Adding up ranked $4^{\text {th }}$ as the most relevant technology, it is possible to use fertilizer to enhance plant growth and to increase productivity but without optimum plant population the farmer cannot obtain optimum yield.

Respondents indicate also that other technologies were relevant for example, timely harvesting (3.57), bird control (3.44) and herbicide use (3.28). It is important to note however, that the respondents do not perceived training on some practices as relevant, because their mean scores were below 2.50: insect control (1.66), hand weeding (1.91), recommended land preparation (2.32) and iron toxicity control (2.37) which ranked $16^{\text {th }}$ $15^{\text {th }}, 14^{\text {th }}$ and $13^{\text {th }}$ respectively. Any practice that is not perceived as relevant by the farmers will not be accepted or adopted because they felt it is not relevant and or compatible with their existing practices. This is in agreement with the finding of van dan Ban and Hawkins, (2002) who find that farmer's perception of improved rice technologies are relative rather than absolute, as such affect the rate of adoption significantly. 
Table 4: Distribution of respondents according to their perception on training received on various types of improved rice technologies

\begin{tabular}{|c|c|c|c|c|c|c|c|c|}
\hline \multirow[b]{2}{*}{ Technologies } & \multicolumn{4}{|c|}{ Rating } & \multirow[b]{2}{*}{$\begin{array}{l}\text { Weighted } \\
\text { Sum }\end{array}$} & \multirow[b]{2}{*}{$\begin{array}{l}\text { Weighted } \\
\text { Mean }\end{array}$} & \multirow[b]{2}{*}{$\begin{array}{c}\text { Overall } \\
\text { Perception }\end{array}$} & \multirow[b]{2}{*}{ Rank } \\
\hline & $\begin{array}{c}\text { Not } \\
\text { Relevant }\end{array}$ & $\begin{array}{c}\text { Slightly } \\
\text { Relevant }\end{array}$ & Relevant & $\begin{array}{c}\text { Very } \\
\text { Relevant }\end{array}$ & & & & \\
\hline $\begin{array}{l}\text { Selection of High } \\
\text { Yielding varieties }\end{array}$ & - & $2(1.3)$ & $4(2.5)$ & 154(96.3) & 632 & 3.95 & Relevant & $1^{\text {st }}$ \\
\hline $\begin{array}{l}\text { Selection of } \\
\text { Healthy seed }\end{array}$ & - & - & $13(8.1)$ & 147(91.9) & 627 & 3.92 & Relevant & $2^{\text {nd }}$ \\
\hline $\begin{array}{l}\text { Recommended } \\
\text { Land }\end{array}$ & $54(33.8)$ & $46(28.8)$ & $15(9.4)$ & $45(28.1)$ & 371 & 2.32 & $\begin{array}{c}\text { Not } \\
\text { Relevant }\end{array}$ & $14^{\text {th }}$ \\
\hline $\begin{array}{l}\text { Preparation } \\
\text { Direct Seeding }\end{array}$ & $2(1.3)$ & $8(5.0)$ & $96(60.0)$ & $54(33.8)$ & 522 & 3.26 & Relevant & $8^{\text {th }}$ \\
\hline Adding Up & $5(3.1)$ & $7(4.4)$ & $26(16.3)$ & $122(76.3)$ & 588 & 3.66 & Relevant & $4^{\text {th }}$ \\
\hline Herbicide Use & $1(0.6)$ & $12(7.5)$ & $88(55.0)$ & $59(36.9)$ & 525 & 3.28 & Relevant & $7^{\text {th }}$ \\
\hline Fertilizer Use & $1(0.6)$ & $8(5.0)$ & $10(6.3)$ & $141(88.1)$ & 611 & 3.82 & Relevant & $3^{\text {rd }}$ \\
\hline Insect Control & $11(6.9)$ & $31(19.4)$ & $7(46.9)$ & $43(26.9)$ & 266 & 1.66 & $\begin{array}{c}\text { Not } \\
\text { Relevant }\end{array}$ & $16^{\text {th }}$ \\
\hline Rodent Control & $13(8.1)$ & $56(35.0)$ & $30(18.8)$ & $61(38.1)$ & 459 & 2.87 & Relevant & $11^{\text {th }}$ \\
\hline Disease Control & $3(1.9)$ & $23(14.4)$ & $90(56.3)$ & $44(27.5)$ & 495 & 3.09 & Relevant & $10^{\text {th }}$ \\
\hline Birds Control & $1(0.6)$ & $47(29.4)$ & $56(35.0)$ & $56(35.0)$ & 487 & 3.44 & Relevant & $6^{\text {th }}$ \\
\hline $\begin{array}{l}\text { Iron Toxicity } \\
\text { Control }\end{array}$ & $56(35.0)$ & $20(12.5)$ & $53(33.1)$ & $31(19.4)$ & 379 & 2.37 & $\begin{array}{c}\text { Not } \\
\text { Relevant }\end{array}$ & $13^{\text {th }}$ \\
\hline $\begin{array}{l}\text { Improved } \\
\text { Nursery } \\
\text { Practices }\end{array}$ & $18(11.3)$ & $54(33.8)$ & $34(21.3)$ & $54(33.8)$ & 444 & 2.78 & Relevant & $12^{\text {th }}$ \\
\hline Hand Weeding & $7(4.4)$ & $22(13.8)$ & $85(53.1)$ & $46(28.8)$ & 306 & 1.91 & $\begin{array}{c}\text { Not } \\
\text { Relevant }\end{array}$ & $15^{\text {th }}$ \\
\hline $\begin{array}{l}\text { Timely } \\
\text { Harvesting }\end{array}$ & $2(1.3)$ & $12(7.5)$ & 39(24.4) & $107(66.9)$ & 571 & 3.57 & Relevant & $5^{\text {th }}$ \\
\hline $\begin{array}{l}\text { Improved } \\
\text { Threshing Floor }\end{array}$ & $6(5.0)$ & $10(6.3)$ & $76(47.5)$ & $66(41.3)$ & 518 & 3.24 & Relevant & $9^{\text {th }}$ \\
\hline
\end{tabular}

Figures in parenthesis are Percentage

Source: Field Survey, 2011.

\section{Respondents Access to Training}

Farmers received training basically from two sources, either from government or nongovernmental organisations (NGOs). Training equips the farmers with the necessary skills to carry out their farm operations and build their self confidence in the technology. $100 \%$ of the participants claimed they had received training on the adoption of improved rice packages as indicated in table 5 , It has a significant mean deference at $\mathrm{P}<0.01$. The table also indicates that participants had more training on technology adoption than the nonparticipants which implies that training is positively associated with adoption.

Table 5: Result of $x^{2}$ on Rice Package Training and Adoption

\begin{tabular}{lcccc}
\hline Training & No Participants $(\mathrm{N}=160)$ & Participants $(\mathrm{N}=160)$ & Total & $\mathrm{X}^{2}$ \\
\hline Yes & $81(50.6)$ & $160(100.0)$ & $241(75.3)$ & $31.958^{\star \star \star}$ \\
No & $79(49.4)$ & - & $79(24.7)$ & \\
\hline Total & $160(100)$ & $160(100)$ & $320(100)$ & \\
\hline
\end{tabular}

***significant at $1 \%$

Source: Field Survey, 2011.

\section{Output and income of participants and non-participants}

Table 6 shows the result of the paired mean difference between the output (35.863) and income (N149113.8) of participants and non-participants showed clearly significant mean 
deference. Implying that training and adoption of improved rice package had a positive and significant effect on output and income.

Table 6: Paired Mean Difference between output and income of participants and non-participants in the training programme

\begin{tabular}{|c|c|c|c|}
\hline Variables & Mean & t-value & Significance \\
\hline $\begin{array}{l}\text { Paired difference in participant and non-participant } \\
\text { output }\end{array}$ & 35.863 & 14.292 & .000 \\
\hline $\begin{array}{l}\text { Paired difference in participant and non-participant } \\
\text { income }\end{array}$ & N149113.8 & 9.949 & .000 \\
\hline
\end{tabular}

Source: Field Survey,

Adoption of improved rice package increase the participants output and income drastically, this was revealed in the mean difference of 35.863 and t-value of 14.292 between participants and non-participants, which is significant at $1 \%$. The mean

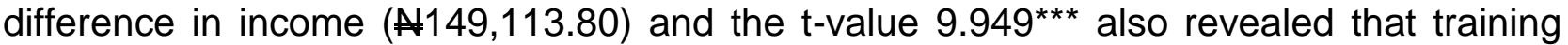
and adoption of improved rice packages had a positive and significant effect on the farmers' output, income and consequently on the household livelihood. Similar results were observed by Tsado and Zakari (2007), who stated that there is significant mean difference in output between beneficiaries and non-beneficiaries of intervention programmes

Difference between the output and income of the participants and non-participants The result on table 7 showed a significant difference between the mean yield and income of participants and non-participants. A positive mean difference in yield of participants (65.39) and non-participants (30.45) implies that there was impact of the programme on the participants. A positive mean difference in income of participants $(\mathrm{A} 308,235.65)$ and non-participants ( $(152,420.63)$ implies that there was impact of the training on the participant's income. On the basis of the above the null hypothesis which states that there is no significant difference between the output and income of the participants and nonparticipants before and after training is hereby rejected.

Table 7: Difference between the output and income of the participants and nonparticipants in the Training Programme.

\begin{tabular}{llll} 
Variables & Mean & t-value & Decision \\
\hline $\begin{array}{l}\text { Output of participants } \\
\text { Versus }\end{array}$ & 65.39 & 14.606 & $\mathrm{H}_{0}$ rejected \\
$\begin{array}{l}\text { Output of non-participants } \\
\text { Income of participants }\end{array}$ & 30.45 & & \\
$\begin{array}{l}\text { Versus } \\
\text { Income of non-participants }\end{array}$ & $\mathrm{N} 308,235.65$ & 11.144 & $\mathrm{H}_{0}$ rejected \\
\hline Soune & $\mathrm{N} 152,420.63$ & & \\
\hline
\end{tabular}

Source: field survey, 2011

Implying that there was a significant difference between participants and non-participants output and income before and after training. Similar results were observed by (Simonyan 2009 and Tsado and Zakari, 2007), who stated that there is significant mean difference in output between beneficiaries and non-beneficiaries of intervention programmes. 
Relationship between respondents' perception about training and adoption of improved rice packages

The result of the chi-square on table 8 indicates that there was a significant and positive relationship ( $X^{2}=31.958$; $P<0.01$ ) between rice farmers' perception of the relevance of training and adoption of improve rice package. The hypothesis which states that there is no significant relationship between rice farmers' perception of training relevance and there adoption of improved rice packages, is hereby rejected, implying that there was a significant and positive relationship between training perception of the respondents and adoption of improved rice packages. According to Pretty (1995), productivity abounds only when farmers use technologies in combination, that is, adopt package of practices. This result agrees with that of Shiferaw and Holder (1998) who stated that farmers' perception about training influence adoption of a technology significantly and positively.

Table 8: Respondents' perception about training and adoption of improved rice packages

\begin{tabular}{lllll}
\hline $\begin{array}{l}\text { Training } \\
\text { perception }\end{array}$ & $\begin{array}{l}\text { Non- } \\
\text { participant }\end{array}$ & Participant & Total & $\mathbf{X}^{2}$ \\
\hline Relevant & $81(50.6)$ & $160(100)$ & $241(73.5)$ & $31.958^{\star * *}$ \\
Not relevant & $79(49.4)$ & $0(0)$ & $79(24.7)$ & \\
Total & $160(100)$ & $160(100)$ & $320(100)$ & \\
\hline
\end{tabular}

Source: field survey, 2011

*** significant at $1 \%$

\section{Conclusion and Recommendations}

Training of rice farmers and their positive perception about various improved technologies enhance their knowledge and skills, and influenced their adoption level. This eventually increased their rice output, income and consequently uplift their standards of living. It is recommended that:

1. Frequent training of the rice farmers in the study area should be given a top-most priority, so that the farmers can obtain optimum yield from the adoption of improved rice packages. Emphasis should be placed on the series of training at different levels for farmers.

2. Farmer-to-farmer extension network should be reinvigorated so that the target population can be covered. Arranging sufficient number of training, field days and demonstration will go along well to equip farmers with production and management skills.

3. There was significant mean difference between the output and income of participants and non-participants in the intervention programme, as such rice farmers should be encouraged and persuaded to take advantage and participate actively in such intervention programmes in order to increase their output and income.

\section{References}

Agbamu, J.U. (2006). "Development communication in Rural Development Communication. Asian institutes for Development communication Kualar, Lumper, Malayisia Vol. 11 (1) pp. $35-49$. 
Akinsehinde, O. A. (2007). Elements of Agricultural Extension Administration: Bounty Press Ltd. Ibadan

Alene D. Erega \& Rashid M. Hassan (2003). Total factor productivity and resource use efficiency of alternative cropping systems in two (2) agro-climatic zones in Eastern Ethiopia. Agricultural economics review, 4(2) 32-46

Alfred, S. D. Y (2000). "Effect of socio-economic characteristics of farmers in food crop marketing in Yagba East local government area of Kog state. In Olowu T.A (Ed). Agricultural Extension and Poverty alleviation in Nigeria: Proceeding of the $6^{\text {th }}$ Annual National Conference of Agricultural Extension society of Nigeria. Pp 151156.

Agbamu, J. U. (1996). A study of agricultural research extension linkages: with focus on Nigeria and Japan. Ph.D thesis. Tokyo University of Agriculture Tokyo, . In essential of Agricultural Communication in Nigeria. By Agbamu, J. U. (2006) pp 55-63.

Asiabaka, C.C., and M, Kenyon (2002). The Development, Dissemination and Adoption of Technologies Directed at Improving Availability of Clean yam planting material in Nigeria and Ghana. Report on a Study Mission Commissioned by UK Government Department for International Development (DFID) Crop Protection. Nigeria.

CIMMYT (1993). The Adoption of Agricultural Technology: A guide for survey design. CIMMYT Economic programme Maxico . pp88 .

Farta Woreda Agricultural Office (2001). Report on Agricultural Activities in Woreda (in Amgaric). Planning and Training Service, Debre-Tabor

Flippo. E.W. (1965). Principles of Personal Management Englewood; New Jersy, U.S.A Prentice Hall Inc.

Ganpat, W. And Sespersad, C. (1996). An analysis of linkage in a Rice based knowledge system in Trinided. Proceedings of $12^{\text {th }}$ Annual conference of the Association for international Agric and Extension education (AIAEE) held at Arington Virginia pp 131 $-136$.

Gould-Brain W; William, E. Sauple \& Richard M. Klemme. (1989). Conservation Tillage: "The Role off Farm and Adoption Characteristics and the Perception of Soil Erosion" Land Economics, 65 (2):167-182.

Negatu, W. \& Parikh, A. (1999). The Impact of Perception and other Factors on the Adoption of Agricultural Technologies in the Market at Jiru Woreda (Dstrict) of Ethiopia .Agricultural Economics 21: PP 205-216.

Olayide, S.O; Eweka, J.A. and Bello-Osagie, V.E. (Eds) (1980). Nigerian Small Farmers: Problems and Prospects In integrated Rural Development CARD. U.I. for BeninOwena River Basin Development Authority, Benin City. PP315.

Ogunbameru, B. O. (2001). Practical Agricultural Administration. Lagos: kuntel Publishing House, PP.163.

Pretty, J. N.(1995). Regenerating Agricultural: Policies and Practices for Sustainability and Self - reliance. Earth scan publication, London. 
Shaib B., Aliyu, A. \& Bakshi, J.S. (1997). Nigeria: National Agricultural Research Strategy Plan, 1996 - 2010. Dept of Agric. Science, Federal Ministry of Agriculture and Natural Resources, Abuja. Intec Printers Limited, Ibadan. 335 Pp.

Shiferaw, B. \& Holden, S. T. (1998). Resource degradation and adoption of land conservation technologies by small holders in the Ethiopia. Pp 37-55

Simonyan, J. B. (2009). Impact assessment of fadama II project on income and productivity of beneficiary in Kaduna. Unpublished Ph.D thesis of the department of agricultural economics and rural sociology, Ahmadu Bello University Zaria.

Tsado, E. K., and I. Zakari (2007). Results of rice production among NASARA rice cooperative members during the 2007 planting season. Technical report. Pp 1-4

Williams, S.K.T (1978). Rural Development in Nigeria. lle-fe; University of Ife Press.

van den Ban, H.W. and H.S. Hawkins; (2002). Agricultural Extension.CBS Publishers and Distributors, 4596/1A, 11-Daryaganj. New Delhi-110002. pp. 1-3. 